\title{
Optymalny projekt przemieszczania wagonów próżnych w hierarchicznych strukturach transportu kolejowego
}

\begin{abstract}
$W$ pracy przedstawiono nowe, efektywne rozwiqzanie zadania zarzqdzania parkiem wagonów próżnych. Opracowano model $i$ algorytm optymalnego rozdziału wagonów próżnych, oparty na czterech waznych zasadach: dekompozycji, agregacji informacji, koordynacji i dezagregacji. Zaproponowany model dekompozycyjny można efektywnie stosować zarówno do korekty planów okresowych, jak również do planowania bieżacego przemieszczania wagonów próżnych.
\end{abstract}

\section{Sformułowanie problemu}

Stałe ulepszanie struktur zarządzania $\mathrm{w}$ transporcie kolejowym pozwala efektywnie zrealizować proces transportowy zarówno w przypadku wzrostu jak i spadku wielkości przewozów. Dotyczy ono również optymalnego planu przemieszczania wagonów próżnych w systemach hierarchicznych. Zadanie to należy do istotnych na wszystkich poziomach zarządzania procesem ruchowym.

Optymalny rozdział wagonów próżnych określa miesięczne plany średniodobowych norm załadunku i wyładunku. Jak wiadomo z praktyki, pomiędzy planem a jego realizacja, w ciaggu miesiąca bardzo często występują odchylenia, likwidowane w sposób intuicyjny, pozbawiony wszelkich cech optymalności.

Odchylenia te można doprowadzić do minimum poprzez decyzje operatywne. Służy temu racjonalna organizacja samej struktury decyzji. Pod strukturą decyzji będzie rozumiany stabilny, przestrzennoczasowy podział rozwiązań i środków, niezbędnych do ich realizacji wraz z istniejaccymi pomiędzy nimi powiązaniami [1].

Zarządzanie systemami złożonymi wymaga opracowania specyficznej struktury decyzji, polegającego na dekompozycji zadania wyjściowego na kilka słabo powiązanych pomiędzy sobą zadań ekstremalnych o mniejszych wymiarach.

Należy przy tym podkreślić, że aspekty dotyczące organizacji i zarządzania w zadaniach dekompozycji są o wiele rzadziej poruszane niż aspekty obliczeniowe.

Istniejąca struktura decyzji, dotyczących rozdziału wagonów próżnych oparta jest na rozwiązaniu zadań o słabo sformalizowanej funkcji celu i warunkach ograniczających [2].

W organizacji przesuwu wagonów próżnych należy również uwzględnić rozporządzenia operatywne władz administracyjnych i terytorialnych, związane z tym przesuwem.
Z punktu widzenia Centrum Zarządzania Ruchem Kolejowym, operator podejmujący decyzje, dotyczące przesuwu wagonów próżnych, powinien zapewnić: minimalny czas przebywania wagonu $\mathrm{w}$ stanie próżnym, minimalny koszt przekazania wagonów próżnych sąsiednim regionom, maksymalny załadunek wagonów na drodze ich biegu itp. [3]. Rozwiązanie tak sformułowanego zadania wymaga optymalizacji wielokrotnej, ze względu na kilka sformalizowanych kryteriów [4].

W planowaniu okresowym przesuwu wagonów próżnych uwzględnia się jedynie pierwsze kryterium, wykorzystując otwarty model transportowy z ograniczeniami zdolności przepustowych [3]:

$$
\left.\begin{array}{lll}
\min _{x} \sum_{i \in R} \sum_{j \in R} c_{i j} x_{i j} ; \quad a & \\
\sum_{k \in K_{i}} x_{i k}-\sum_{l \in L_{i}} x_{l i}=r_{i} ; & b \\
\sum_{h \in H_{j}} x_{h i}-\sum_{s \in S_{j}} x_{j s}=p_{j} ; \quad c & \\
\sum_{j \in R} p_{j}<>\sum_{i \in R} r_{i} ; \quad d & \\
x_{i j} \geq 0 ; \quad e \\
x_{i j} \leq d_{i j} ; \quad f
\end{array}\right\}
$$

gdzie: $c_{i j}$ - koszt przesuwu wagonu próżnego pomiędzy punktami $i$ i $j ; x_{i j} \in X$ - liczba wagonów próżnych przekazywanych pomiędzy punktami $i \mathrm{i} j ; d_{i j}$ - zdolność przepustowa $i j-$ tego kierunku $\mathrm{w}$ odniesieniu do wagonów próżnych; $R$ - zbiór stacji załadunku i wyładunku; $r_{i}$ - nadmiar wagonów próżnych $\mathrm{w} i$ - tym punkcie; $K_{i}, S_{j}$ - zbiór punktów przyjmujących wagony próżne odpowiednio z punktów $i \mathrm{i} j ; L_{i}, H_{j}$-zbiór punktów zdających wagony próżne odpowiednio do punktów $i \mathrm{i} j$. 
Rozwiązaniem zadania (1) jest optymalny plan $\left\{x_{i j}^{*}\right\}$ dobowych norm zdania - przyjęcia wagonów próżnych. W praktyce normy te są bardzo często nie wypełniane. Podejmowane decyzje bazują często na doświadczeniu i intuicji samych decydentów. Zadanie efektywnego zarządzania parkiem wagonów próżnych staje się zatem niezwykle ważnym i aktualnym.

\section{Model dekompozycji i algorytm rozdziału wagonów próżnych}

Rozważmy możliwość rozwiązania zdania (1) w strukturze hierarchicznej pokazanej na rys. 1 .

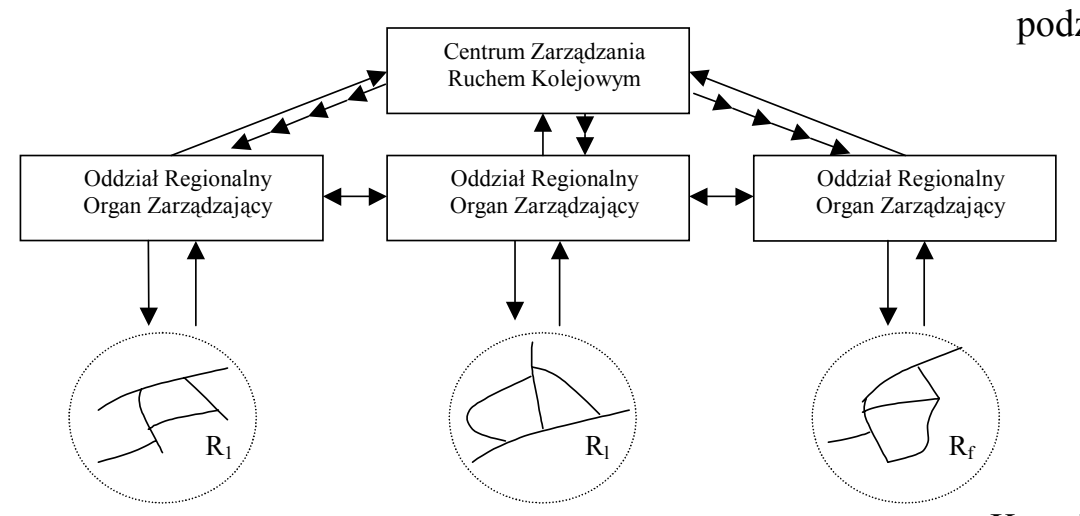

Istnieją różne podejścia do budowy algorytmów optymalizacji wielostopniowej [5]. W pierwszej kolejności wymienić należy prace Dantziga [6] które dotyczą programów komputerowych służących rozwiązywaniu zadań o dużych rozmiarach. Idea tych programów sprowadza się do następujących spostrzeżeń [ 6]:

1. Zadanie wyjściowe dekomponuje się na szereg podzadań, powiązanych pomiędzy sobą ograniczeniami, dotyczącymi rozdzielanych wagonów próżnych;

2. Ceny w zadaniu koordynacji traktowane są jako zmienne podwójne;

3. Koszty dodawane są do funkcji celu każdego podzadania.

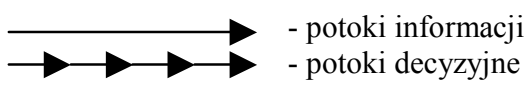

Rys. 1. Dwupoziomowa hierarchiczna struktura zarządzania parkiem wagonów próżnych

W strukturze tej sieć kolejowa dzieli się na słabo powiązane między sobą, pod względem wymiany wagonów próżnych, regiony. W rozpatrywanej strukturze Centrum Zarzadzania Ruchem Kolejowym stanowi poziom górny i koordynuje wzajemne relacje pomiędzy regionami, tj. rozwiązuje zadania koordynacji w zbiorze:

$$
R^{* *}=\left\{(i, j): i \in R_{l} \Leftrightarrow j \notin R_{l} ; l=\overline{1, f}\right\}
$$

gdzie: $R_{l}$ - zbiór wierzchołków należących do regionu $l, f$ - liczba regionów.

Poziom dolny stanowią Oddziały Regionalne, obejmujące okręgi kolejowe. Zadanie (1) rozwiązywane na poziomie regionalnym będziemy nazywać lokalnym. Dowolna para wierzchołków $i, j$, rozpatrywanego $l$ - tego zadania lokalnego odpowiada zależności:

$$
i \in R_{l} \Leftrightarrow j \notin R_{l} ; l=\overline{1, f}
$$

Zamieńmy zadanie (1) ekwiwalentnym systemem prostych zadań planowania przesuwu taboru próżnego, rozwiązywanych na poziomie każdego regionu. Biorąc pod uwagę wzajemne powiązania pomiędzy regionami, rozwiązanie ogólne zadania (1) powinno uwzględniać wszystkie rozwiązania cząstkowe, zaś organ zarządzający, na poziomie górnym winien spełniać funkcję koordynująca.
Rozwiązanie zadania uzyskuje się na podstawie wymiany informacji, podczas której poziom górny przekazuje poziomowi dolnemu koszty przesuwu i liczbę wagonów próżnych. Rozwiązanie optymalne zadania wyjściowego stanowi liniowa wypukła kombinacja rozwiązań optymalnych zadań cząstkowych.

Koordynator podejmując decyzję optymalna, bierze pod uwage rozwiązania zaproponowane przez poszczególne regiony. Konieczność iteracyjnej wymiany informacji pomiędzy poziomem górnym i dolnym dodatkowo zwiększa istniejący, gigantyczny potok informacji i czyni przedstawiony algorytm mało przydatnym w poszukiwaniu optymalnego planu przesuwu wagonów próżnych.

Teoretycznie, do rozwiązania w/w zadania, można zastosować metodę dekompozycji zadania transportowego zaproponowana przez Lesdona [5]. Metoda ta daje rezultaty zadawalające, jedynie w tych zadaniach, w których liczba wierszy jest o wiele większa od liczby kolumn (lub odwrotnie). Jednak i w tym przypadku powstaje problem wymiany informacji pomiędzy poziomami.

Realizacja tego algorytmu przewiduje kroki następujące:

Krok 1. Określenie rozwiązania dopuszczalnego $\left\{\widetilde{x}_{i j}\right\}$ zadania (1).

W charakterze rozwiązania dopuszczalnego można wybrać istniejący, realny plan zarządzania parkiem wagonów próżnych.

Krok 2. Likwidacja przeciwnych potoków wagonów próżnych, znajdujących się w planie $\left\{\widetilde{x}_{i j}\right\}$.

W kroku tym określane sa: $\min \left\{x_{i j}, x_{j i}\right\}$ oraz nowe wartości $x_{i j}^{1}$ i $x_{j i}^{1}$ według wzorów:

$$
\begin{aligned}
& x_{i j}^{1}=x_{i j}-\min \left\{x_{i j}, x_{j i}\right\} \\
& x_{j i}^{1}=x_{j i}-\min \left\{x_{i j}, x_{j i}\right\}
\end{aligned}
$$


Z zależności (2) jasno wynika, że jeden z potoków przyjmie wartość zero, tj. zostanie zlikwidowany.

Krok 3. Rozbicie optymalne $\mathrm{w}^{*}$ wyjściowego

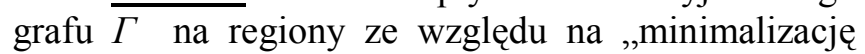
powiązań”.

Plan $\left\{\tilde{x}_{i j}\right\}$ stanowi informację wyjściową do rozbicia ${ }^{*}{ }^{*}$, które sprowadza się do budowy grafu $\Gamma^{w^{*}}$ na bazie grafu wyjściowego $\Gamma$ poprzez odrzucenie pętli i łuków równoległych. Wierzchołkami grafu $\Gamma^{w^{*}}$ są regiony $R_{l}^{w^{*}}$. Wierzchołki regionów $R_{k}^{w^{*}}$ i $R_{l}^{w^{*}}$ połączone są łukiem tylko wtedy, gdy w grafie $\Gamma$ istnieje łuk skierowany od wierzchołka $r_{i} \in R_{k}^{w^{*}}$ do wierzchołka $r_{j} \in R_{l}^{w^{*}}$. Łuki grafu $\Gamma^{w^{*}}$ posiadają następujące parametry:

$$
x_{k l}^{w \cdot}=\sum_{i \in R_{k}, j \in R_{l}} \tilde{x}_{i j}
$$

gdzie $l, k=\overline{1 ; f\left(w^{*}\right)} ; l \neq k$

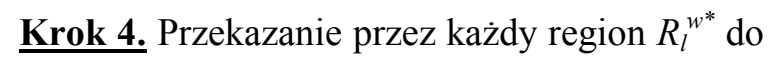
górnego poziomu zarządzania zawartości zmiennych

$$
\Delta_{l}=\Delta_{l}\left(R_{l}^{w^{*}}\right)=\sum_{i \in R_{L}^{w^{*}}} r_{i}-\sum_{j \in R_{L}^{w^{*}}} p_{j}
$$

Krok 5. Klasyfikacja w górnym poziomie zarządzania, zbioru regionów $\left\{R_{l}^{w^{*}}\right\} \quad\left(l=\overline{1 ; f\left(w^{*}\right)}\right)$ na trzy podzbiory:

a) neutralne, jeżeli $\Delta_{l}=0$;

b) zasilane, jeżeli $\Delta_{l}>0$;

c) konsumpcyjne, jeżeli $\Delta_{l}<0$. podziału.

Krok 6. Ujawnienie szczególnych przypadków

Po krokach 4 i 5 mogą zaistnieć dwa przypadki:

a) spełniona jest równość (1d) i istnieją regiony tylko neutralne,

b) spełniona jest równość (1d) i brak jest regionów konsumpcyjnych.

Jeżeli zachodzi jeden $\mathrm{z}$ wymienionych przypadków, to zbiór $X$ może być podzielony na dwa nie przecinające się podzbiory $X^{i}, i=\overline{1, f}$, przy czym $X^{i} \Leftrightarrow R_{i}, i=\overline{1, f}, \mathrm{tj}$. powiązania pomiędzy regionami są zerowe i optimum globalne równe jest sumie rozwiązań lokalnych.

Tak więc, w przypadku szczególnym (krok 6a) optymalny plan przesuwu wagonów próżnych $\left\{X_{i j}^{*}\right\}$ składa się jedynie $\mathrm{z}$ optymalnych planów lokalnych $\left\{X_{i j}^{* l}\right\}$. W przypadku szczególnym (krok 6b) należy dokonać modyfikacji powiązań regionalnych.

Krok 7. Modyfikacje powiązań regionalnych. Do regionów $\mathrm{z}$ nadmiarem wagonów próżnych wprowadza się $(n+1)$-szy fikcyjny punkt niedoboru wagonów próżnych:

$$
\begin{aligned}
& p_{n+1}=\sum_{i \in R_{l}} r_{i}-\sum_{j \in R_{l}} p_{j} ; \\
& T_{i, n+1}=0 ; \quad d_{i, n+1}=\infty
\end{aligned}
$$

gdzie $n$ - liczba punktów niedoboru wagonów próżnych, w sieci wyjściowej $l$-tego regionu.

$\mathrm{W}$ regiony $\mathrm{z}$ niedoborem wagonów próżnych wprowadza się $(m+1)$-szy fikcyjny punkt $\mathrm{z}$ nadmiarem wagonów próżnych:

$$
r_{m+1}=\sum_{j \in R_{q}} p_{j}-\sum_{i \in R_{q}} r_{i} ; \quad T_{m+1, j}=0 ; \quad d_{m+1, j}=\infty
$$

gdzie $m$ - liczba punktów z nadmiarem wagonów próżnych, w wyjściowej sieci $q$-tego regionu. W charakterze punktów fikcyjnych występują punkty graniczne regionu.

$\mathrm{W}$ rezultacie przeprowadzonej modyfikacji otwarte zadania lokalne stają się zamkniętymi.

Krok 8. Wydzielenie elementów zbioru międzyregionalnych punktów granicznych $R^{* *}$ dla rozwiązania zadania koordynacji (patrz rys. 2)

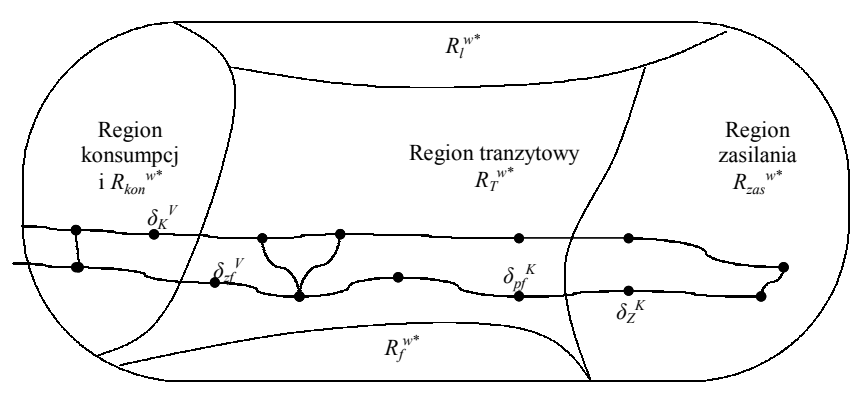

Rys. 2. Wybór międzyregionalnych punktów granicznych.

Krok 9. Rozwiązanie zadania transportowego (1) w grafie $\Gamma^{w^{*}}$ i zbioru $R^{* *}$, przez górny poziom zarządzania i przekazanie planu optymalnego poziomowi dolnemu.

Krok 10. Określenie struktury współpracy pomiędzy regionami. Wyznaczenie regionów zasilania, konsumpcji i tranzytowych. Regiony tranzytowe przekazują wagony próżne od regionów zasilania do regionów konsumpcji. Możliwa struktura współpracy pomiędzy regionami pokazana została na rys. 2 .

Krok 11. Rozwiązanie zadania współpracy pomiędzy regionami, w poziomie dolnym, rozpoczyna się od rozwiązania zadania lokalnego $\mathrm{w}$ regionie zasilania.

W rozwiązaniu zadania lokalnego wykorzystuje się informację, przekazywaną przez region tranzytowy regionowi zasilania, dotyczącą położenia punktów granicznych, przez które będą przyjmowane wagony próżne, oraz dotyczącą zdolności przepustowej wybranych kierunków tranzytowych. Informacja ta może być wykorzystana przez regiony zasilania $\mathrm{w}$ formie ograniczeń. 
Po uwzględnieniu wszystkich ograniczeń wewnątrz regionu zasilania, rozwiązuje się zamknięte zadania transportowe.

Krok 12. Przekazanie informacji regionowi tranzytowemu, dotyczącej rozwiązania zadania lokalnego rejonu zasilania, po czym region tranzytowy przystępuje do rozwiązania swojego zadania lokalnego.

Krok 13. Wprowadzenie fikcyjnych punktów przyjęcia i zdania wagonów próżnych $\mathrm{w}$ regionach tranzytowych. Umożliwi to optymalizować zadanie lokalne $\mathrm{w}$ regionie tranzytowym, $\mathrm{z}$ uwzględnieniem punktów tranzytowych.

Dla każdego $k$-tego punktu przyjęcia wagonów próżnych, z regionu zasilania wprowadza się fikcyjny punkt produkcyjny o wydajności $\delta_{p f}^{K}$, równej wydajności realnego punktu zdania wagonów próżnych $\delta_{z}^{K}$, regionu zasilania.

$Z$ drugiej strony, dla każdego $v$-tego punktu granicznego, przekazującego wagony próżne w region konsumpcji, wprowadza się fikcyjny punkt konsumpcji o zapotrzebowaniu $\delta_{z f}^{V}$, równym zapotrzebowaniu realnego punktu konsumpcji $\delta_{k}^{V}$ regionu konsumpcji (rys. 2). W charakterze punktów fikcyjnych wykorzystuje się realne punkty graniczne regionów.

Wprowadzenie punktów fikcyjnych zmienia strukturę warunków ograniczających $(1 \mathrm{~b}-1 \mathrm{~d})$ zadania lokalnego dla regionu tranzytowego:

$$
\left.\begin{array}{lrr}
\sum_{i \in R_{T}^{w}} x_{i j}=r_{j}+\delta_{z f}^{j} ; & \text { dla } & j \in\{T\}, \\
\sum_{i \in R_{T}^{w}} x_{i j}=r_{j} ; & d l a & j \notin\{T\}, \\
\sum_{i \in R_{T}^{w}} x_{i j}=p_{i}+\delta_{p f}^{i} ; & d l a & i \in\{S\}, \\
\sum_{i \in R_{T}^{w}} x_{i j}=p_{i} ; & d l a \quad i \notin\{S\}, \\
\sum_{j \in R_{T}^{w}} r_{j}+\sum_{K=1}^{s} \delta_{p f}^{K}<>\sum_{i \in R_{T}^{w}} p_{i}+\sum_{V=1}^{t} \delta_{z f}^{V}
\end{array}\right\}
$$

Gdzie $\{S\}-$ zbiór punktów granicznych przekazywania wagonów próżnych $\mathrm{z}$ regionów zasilania do regionów tranzytowych,

$\{T\}$ - zbiór punktów granicznych przekazywania wagonów próżnych $\mathrm{z}$ regionów tranzytowych do regionów konsumpcji,

$s-$ liczba punktów granicznych w $\{S\}$,

$t$ - liczba punktów granicznych $\mathrm{w}\{T\}$.

Uwzględniając dla regionu tranzytowego zależność:

$$
\sum_{k=1}^{s} \delta_{p f}^{k}=\sum_{v=1}^{t} \delta_{z f}^{v}
$$

wprowadzenie punktów fikcyjnych nie zakłóca początkowego warunku równowagi i nie zmienia struktury regionu (patrz krok 5).

Krok 14. Sprawdzenie lokalnych warunków równowagi $\mathrm{w}$ regionie tranzytowym, $\mathrm{i} \mathrm{w}$ razie ich zakłócenia, modyfikacja ograniczeń (3) zadania lokalnego.

Modyfikacja polega na przekształceniu otwartego zadania transportowego $\mathrm{w}$ zadanie zamknięte, $\mathrm{tj}$. wprowadzeniu $(n+1)$ - go punktu konsumpcji, takiego, że:

$$
\begin{array}{ll}
p_{n+1}=\sum_{i \in R_{T}^{w}} p_{i}-\sum_{j \in R_{T}^{w}} r_{j}, \\
d_{i, n+1}=\infty ; \quad c_{i, n+1}=0
\end{array}
$$

Krok 15. Rozwiązanie lokalnego zamkniętego zadania $\mathrm{w}$ regionie tranzytowym.

W rozwiązaniu tym mogą być uwzględnione możliwości regionu konsumpcji, poprzez wprowadzenie ograniczeń dodatkowych. Odpowiednie zdolności przepustowe $\left(d_{i, v} ; d_{k j}\right)$ i koszty przewozów $\left(c_{i v} ; c_{k j}\right)$ są takie same jak dla punktów granicznych regionów leżących na drodze tranzytowego potoku wagonów próżnych.

Krok 16. Rozwiązanie zadania lokalnego w regionie konsumpcji.

Rozwiązanie to uzyskuje się na bazie informacji o przesuwie wagonów próżnych przez punkty graniczne, przekazanej przez region tranzytowy, po rozwiązaniu jego zadania lokalnego (patrz krok 15).

W wyniku rozwiązania lokalnych zamkniętych zadań transportowych uzyskuje się plan $\left\{x_{i j}^{l}\right\}, l=\overline{1, f}$, zaś $\mathrm{w}$ regionach $\mathrm{z}$ nadmiarem (niedoborem) wagonów próżnych dodatkowo - lokalno - optymalne punkty zdania (przyjęcia) oraz lokalno - optymalne wielkości potoku, przekazywanego przez każdy z regionów.

W przypadku równości warunku (1d), w celu zapewnienia optymalnego międzyregionalnego przesuwu wagonów próżnych, górny poziom zarządzania rozwiązuje zadanie koordynacji w zbiorze $R^{* *}$. W wyniku tego rozwiązania, nadmiar wagonów próżnych, w określonych regionach, pokrywa niedobór tych wagonów w innych regionach.

W przypadku nierówności warunku (1d) należy rozwiązać problem czasowego wykorzystania wagonów próżnych. Mogą one pozostać w dyspozycji regionu lub być przekazane do wykorzystania przez inne regiony. W szczególnym przypadku, górny poziom zarząadzania, może wydać dyspozycję utworzenia rezerwy operatywnej, która będzie wykorzystana w czasie deficytu wagonów próżnych. Rezerwa ta może w przyszłości być wykorzystana zarówno przez region, który w danej chwili dysponuje nadmiarem wagonów próżnych, jak i przekazana innym regionom. W ostatnim przypadku, przed wykonaniem kroku 7 niedobór wagonów próżnych w tych regionach, sztucznie 
zwiększa się o wielkość planowanej rezerwy, w wyniku czego, otwarte zadanie koordynacji sprowadza się do zadania zamkniętego. $\mathrm{W}$ ten sposób, górny poziom zarządzania, praktycznie zawsze rozwiązuje zamknięte zadanie transportowe. Wyjątek stanowi mało prawdopodobny przypadek akumulacji nadmiaru wagonów próżnych $\mathrm{w}$ międzyregionalnych punktach granicznych, przy braku decyzji o jego dalszym przemieszczaniu. W takim razie do zbioru $R^{* *}$ dodaje się fikcyjny $(v+1)$ - szy punkt graniczny $(v-$ liczba międzyregionalnych punktów granicznych z niedoborem wagonów próżnych):

$$
\begin{aligned}
& p_{v+1}=\sum_{i \in R} r_{i}-\sum_{j \in R} p_{j} ; \\
& T_{i, v+1}=0 ; \quad d_{i, v+1}=\infty,
\end{aligned}
$$

czyli otwarte zadanie transportowe sprowadza się do zamkniętego. W wyniku jego rozwiązania uzyskuje się optymalny plan przesuwu wagonów próżnych przez międzyregionalne punkty graniczne $\left\{x_{i j}^{* *}\right\}$.

Funkcjonał (1a), w wyniku przedstawionego algorytmu, przyjmuje następującą postać:

$$
\sum_{l=1}^{f} \sum_{i \in R_{l}} \sum_{j \in R_{l}} T_{i j} x_{i j}^{* l}+\sum_{i \in R^{* *}} \sum_{j \in R^{* *}} T_{i j} x_{i j}^{* *} \rightarrow \min
$$

Zaproponowany dekompozycyjny algorytm rozdziału wagonów próżnych bazuje na czterech ważnych zasadach:

1) Dekompozycji - rozwiązanie ogólne zadania (1) składa się z rozwiązań szczegółowych zbioru lokalnych zadań regulacji parku wagonów próżnych, dotyczących każdego regionu;

2) Agregacji informacji - na górny poziom zarządzania przekazywana jest ogólna informacja o stanie każdego regionu;

3) Koordynacji - górny poziom zarządzania rozwiązuje zadanie koordynacji, określające zasady współpracy regionów na poziomie dolnym;

4) Dezagregacji - przekazywane z górnego poziomu zarządzania rozwiązanie koordynujące wykorzystywane jest, z uwzględnieniem informacji dodatkowej, generowanej przez poziom dolny, do rozwiązania zadań lokalnych.

Algorytm ten, w co najmniej dwóch kwestiach, różni się od znanych algorytmów dekompozycyjnych [5].

Po pierwsze, nie wymaga ,iteracyjnej” wymiany informacji zarówno na danym poziomie jak i pomiędzy różnymi poziomami zarządzania. Tym samym pozwala rozwiązać dane zadanie, wykorzystując standardowe technologie informatyczne, znajdujące się w każdym regionie.
Po drugie, wartość funkcjonału (1a), w wyniku zastosowania przedstawionego algorytmu, może znacznie różnić się od ogólnego rozwiązania optymalnego zadania (1) w warunkach pełnej centralizacji zarządzania. Rezultaty jednakowe możliwe są jedynie $\mathrm{w}$ przypadku szczęśliwie wybranych punktów granicznych, lub jeżeli uzyskano tylko regiony neutralne. W tym przypadku optimum globalne równe jest sumie optimów lokalnych.

\section{Oszacowanie wielkości błędu obliczeń}

Przy dowolnej strukturze regionów, błąd obliczeń, generowany przez zaproponowany algorytm, nie przewyższa wartości dopuszczalnej, wynikającej $\mathrm{z}$ niedostatecznej operatywności zarządzania. Wynika on z faktu, że realne czasy $\widetilde{T}_{i, n+1}, \widetilde{T}_{m+1, j}$ przekazania wagonów próżnych do międzyregionalnych punktów granicznych są różne od zera.

Dokładne jego określenie wymaga obliczenia następującej sumy:

$$
\sum_{l=1}^{t} \sum_{i \in R_{l}} \sum_{j \in R_{l}}\left(V_{j}-U_{i}-T_{i j}\right) X_{i j}^{* l}+\sum_{i \in R^{* *}} \sum_{j \in R^{* *}}\left(V_{j}-U_{i}-T_{i j}\right) X_{i j}^{* *},
$$

gdzie $V_{j}, U_{i}$ - potencjały wierzchołków $(j, i)$ uzyskane w wyniku rozwiązania, opartego na logice zadania (1) w zbiorze $R$. Oceńmy górną granicę otrzymanego błędu. Oznaczmy: $a$ - liczbę regionów z nadmiarem wagonów próżnych, $l-$ liczbę regionów $\mathrm{z}$ niedoborem wagonów próżnych, $R^{+}$- zbiór regionów $\mathrm{z}$ nadmiarem, $R^{-}$- zbiór regionów z niedoborem wagonów próżnych.

Błąd w regionie z nadmiarem wagonów próżnych nie przekroczy wielkości:

$$
\delta_{1 q}=\sum_{i \in R_{q}} \widetilde{T}_{i, n+1} \sum_{j \in R_{q}} X_{i j}^{* q}
$$

$\mathrm{Z}$ drugiej strony:

$$
\delta_{1 q} \leq \delta_{2 q}=\max _{i \in R_{q}}\left\{\widetilde{T}_{i, n+1}\right\} \sum_{i \in R_{q}} \sum_{j \in R_{q}} X_{i j}^{* q}=\max _{i \in R_{q}}\left\{\widetilde{T}_{i, n+1}\right\} r_{q}^{\prime}
$$

gdzie: $r_{q}^{\prime}$ - ogólna liczba wagonów próżnych regionu $q$.

Wtedy błąd, dotyczący wszystkich regionów z nadmiarem wagonów próżnych wynosi:

$$
\delta_{3}=\sum_{q=1}^{a} \delta_{1 q} \leq \sum_{q=1}^{a} \max _{i \in R_{q}}\left\{\widetilde{T}_{i, n+1}\right\} \gamma_{q}^{\prime} \leq \max _{i \in R^{+}}\left\{\widetilde{T}_{i, n+1}\right\} \sum_{q=1}^{a} r_{q}^{\prime}
$$

Analogicznie można określić błąd, dla regionów z niedoborem wagonów próżnych:

$$
\delta_{4} \leq \max _{j \in R^{-}}\left\{\widetilde{T}_{m+1, j}\right\} \sum_{k=1}^{b} p_{k}^{\prime}
$$

gdzie $p_{k}^{\prime}$ - ogólna liczba wagonów próżnych, przyjmowana przez $k-t y$ region. 
Uwzględniając, że $\sum_{k=1}^{b} p_{k}^{\prime}=\sum_{q=1}^{a} r_{q}^{\prime}$ otrzymamy ostateczną zależność wyznaczająca górną granicę błędu:

$$
\delta \leq \delta_{3}+\delta_{4}=\left(\max _{i \in R^{+}}\left\{\widetilde{T}_{i, n+1}\right\}+\max _{j \in R^{-}}\left\{\widetilde{T}_{m+1, j}\right\}\right) \sum_{q=1}^{a} r_{q}^{\prime}
$$

Należy przy tym podkreślić, że w przypadku dużych systemów realnych, optimum globalne może okazać się nieosiagalnym. Wynika to przede wszystkim z nieokreśloności informacji, wpływającej na wyniki rozwiązań. Jeżeli informacja i hipotezy, na których bazuje model optymalizacji są dostatecznie dokładne, to można uzyskać rozwiązania zadowalające. Parametry modelu (1), na skutek działania czynników różnych (zmniejszenie zdolności przepustowej, zmiana zapotrzebowania itp.) będa podlegały częstym zmianom. Zaprezentowany algorytm będzie $\mathrm{w}$ takich sytuacjach podnosił jakość podejmowanych decyzji.

\section{Podsumowanie}

Reasumując, przeprowadzimy ocenę możliwości operatywnych, jakie pojawiają się podczas realizacji przedstawionych zasad dekompozycji i koordynacji. Zasady te umożliwiają górnemu poziomowi zarządzania spełniać następujące funkcje: poszukiwania dopuszczalnego planu globalnego przesuwu taboru próżnego, realizacji algorytmu rozdziału wagonów próżnych i poszukiwania planu optymalnego zadania koordynacji.

Wiadomym jest, że rozmiar zadania koordynacji jest o wiele mniejszy niż zadania wyjściowego. W związku z tym objętość informacji, niezbędna górnemu poziomowi zarządzania do podjęcia decyzji ulega znacznej redukcji. Poszukiwanie planu optymalnego, zadania lokalnego dla regionów, dysponujących centrami obliczeniowymi nie stanowi istotnego problemu. Rejony przejmują całość zarządzania operatywnego. Dzięki temu nie ponoszą konsekwencji decyzji błędnych, podejmowanych przez innych. W przypadku zmiany planu wewnątrz regionu, organ zarządzający regionem może określić nowy plan przemieszczania wagonów próżnych, minimalizując straty własne. W sytuacjach krytycznych, do likwidacji ich następstw może bez ograniczeń przystapić organ zarządzający, usytuowany w poziomie górnym.

Tak więc pojawia się realna możliwość wykorzystania opracowanego modelu dekompozycyjnego do efektywnej korekty planów okresowych, a także do planowania bieżącego przemieszczania wagonów próżnych, co podniesie operatywność i jakość zarządzania procesem ruchowym.

\section{Bibliografia}

[1] Hall A.D.: Podstawy teorii systemów. PWN, Warszawa 1968.

[2] Тулупов Л.П., Митасов П.В, Пеккер А.Д.: Регулирование парка порожних вагонов $c$ учетом их годности под погрузку. Вестник ВНИИЖТ, 1981, №3

[3] Niestierow E. P.: Programowanie liniowe w transporcie. WKiE, Warszawa 1974.

[4] Кутыркин А.В., Кадушин А. И.: Полиоптимизационная модель регулирования порожних вагонопотоков в АСУЖТ. Труды МИИТа, вып. 637,1979

[5] Лэсдон Л.С.: Оптимизачия больших систем. «Наука», 1975

[6] Dantzig G.B.: Programming in linear structure. Econometrica 1949.

[7] Месарович М., Мако Д., Такахара И.: Теория иерархических многоуровневых систем. М. «Mup», 1973 